\title{
Spatial Geomorphic Deterministic Approach on Land Use \& Change of Agricultural Practice of Purba Medinipur Coastal Area, W.B., India - A Case Study
}

\author{
Sanat Kumar Purkait ${ }^{1}$, Binod Kumar Sardar ${ }^{2}$, Chandan Karan ${ }^{3}$, Sudipta Das ${ }^{4}$ \\ ${ }^{1}$ (Assistant Professor, Department of Geography, Raidighi College, University of Calcutta, W.B., India) \\ ${ }^{2}$ (Assistant Professor, Department of Geography, Y.S. Palpara Mahavidyalaya, Purba Medinipur, W.B., India) \\ ${ }^{3}$ (Research scholar, Department of Geography, Ranchi University, Ranchi, Jharkhand, India) \\ ${ }^{4}$ (Department of Geography, Y.S. Palpara Mahavidyalaya, Purba Medinipur, W.B., India)
}

\begin{abstract}
Coastal area is a dynamic geomorphic unit. Many geomorphic processes are the playing role on coastal area and also deterministic events have been dominated on land use pattern and agricultural practice. Floods, shifting of shoreline, shifting of sand dune, salt water invasion ,coastal and river bank erosion are the most effective geomorphic process, which are the determinant to change of agricultural practice and pattern. Agricultural land, fish farm, saltpan, grazing land, forest land and also settlement are changing due to coastal geomorphic deterministic way. Coastal erosion and shifting of dunes are very sensitive issue for agricultural practice of Kanthi coastal plain. The rate of coastal erosion about 8-12m/year and shifting of dune rate about 6$8 \mathrm{~m} /$ year. The sand dunes are shifting towards the land and also capture the agricultural land, as a result change of cropping pattern is found in this area. Food crops cultivation, commercial crop cultivation, horticulture, aquaculture are affected due to timely action of geomorphic hazards.
\end{abstract}

Key words: Coastal geomorphic process, Geomorphic Deterministic approach, Agricultural land use, Land use changes, Socio-economic change.

\section{INTRODUCTION}

Coastal area is a dynamic geomorphic unit. Coastal zone includes of land-sea interaction with complex environmental setting. Many geomorphic processes are playing the crucial role on the coastal area. Wind and Tidal waves base activity, salt-sediment base activities are the most important processes in coastal geomorphic area. Coastal floods, shifting of shoreline, shifting of sand dune, salt water invasion, coastal and river bank erosion are the most effective geomorphic process and environmental change.

\section{ROLE OF GEOMORPHIC PROCESSES ON THE STUDY AREA}

Coastal geomorphic deterministic events are dominated on land use pattern and agricultural practice in Contai (Kanthi) coastal area. Agricultural land, fish farm, saltpan, grazing land, forest land and also settlement area are changing due to coastal geomorphic deterministic events in this study area. Food crops cultivation, commercial crop cultivation, horticulture, aquaculture are effected due to temporal and seasonal action of geomorphic hazards.

\section{LOCATION AND IDENTIFICATION}

Kanthi coastal tract under Contai subdivision in Purba -Medinipur, W.B.(INDIA) sprawl over the

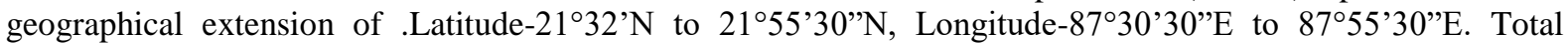
length of coastal tract $-50 \mathrm{Km}$ along the coast. Total geographical area $-75 \mathrm{sq} \mathrm{km}$. which is consisted of Ramnagar Block-I \& II under the Kanthi coastal plain. Ramagar -I \& II Block spreads over 6 villages viz Dolbolda village, Lachimpur village, Jamra village, Somaibosan, Gongadharpur, Jogaibosan. The geographical area is cover by SOI Toposheet no $73 \%, 63 \%$, $10,73^{\circ} / 16$ and Indian $108-57$ (IRS-LISS-3) 


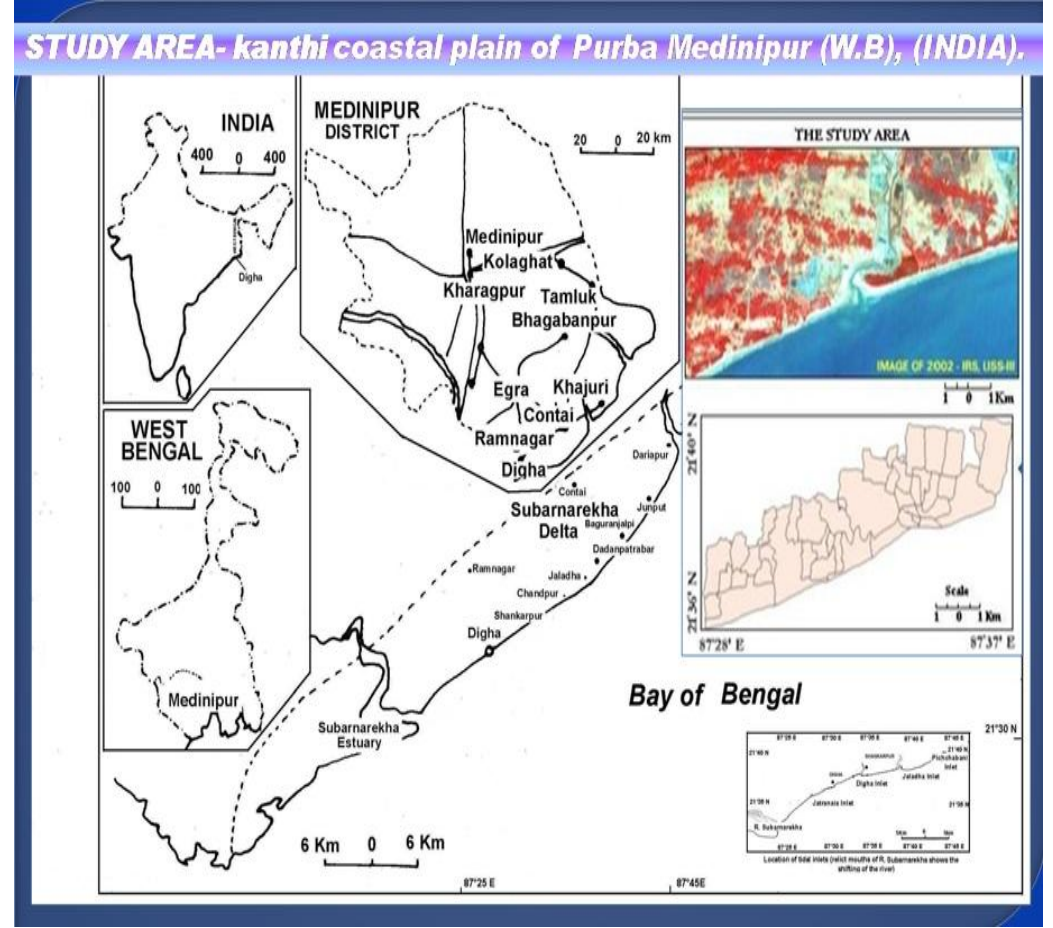

\section{PROBLEMES TO BE INVESTIGATED}

Geomorphic terrain base coastal flood, coastal erosion, Shifting of Sand dune affected problems and their impact on agricultural land use and agricultural practice are to be taken into consideration. Changing land use pattern due to geomorphic aspect on study area \& Food crops based agricultural crop field rapidly change into commercial crops field in and around the study area. Socio economic condition of the study area is to be investigated.

\section{OBJECTIVES}

The authors analyze the present research questionnaire with some of the specific objectives which are noted below.-To study the geomorphic aspect of the study area.

1. To analyze the Coastal flood, Shifting of Sand dune, salt water invasion related problems in the study area.

2. To assess the geomorphic determinism on agricultural practice in the study area.

3. To find out the land use pattern of the study area.

4. To recommend fruitful suggestions for the proper planning of land use pattern and agricultural practice.

\section{METHODOLOGY}

The present research work includes a number of geomorphic analyses. Geomorphic terrain, slope based drainage alignment, soil structural-textural characteristics etc. have been analyzed into qualitative and quantitative approach. Literature survey, census survey, climatic data study, topographical map study and administrative map-data study along with pre-field work. Field work related with intensive field survey along with physical and socio-economic parameter based land use survey and perception survey in the study area. Post field work is related with geographic techniques based measurement and analysis through qualitative and quantitative approach.

\section{GEOMORPHOLOGY \& GEOMORPHIC ASPECT OF THE STUDY AREA}

Average surface elevation of the study area ranges in between 0 to $6 \mathrm{~m}$ above the mean sea level. Gentle slope (below $10^{\circ}$ ) formation is the most important parameter of this area. Most part of the area is occupied by the coastal alluvial and older alluvial based sandy \& sandy loamy soil. 55\% area is covered by Contai basin when $20 \%$ area is covered by Mogra basin and also10\% area sprawls over Chandpur basin. Seasonal and coastal floods are the most effective morphological events in and around a wide geographical coverage under Ramnagar Block-I \& II, Kanthi Block-I, II \& III and attached Municipality, Khajuri Block-I \& II, Nandigram-I \& II, Chandipur. The terrain morphology of Part of Bhagabanpur -II is determined by coastal and seasonal flood, coastal erosion, salt water invasion and shifting of sand dune are the resultant factors of the said terrain morphology. 

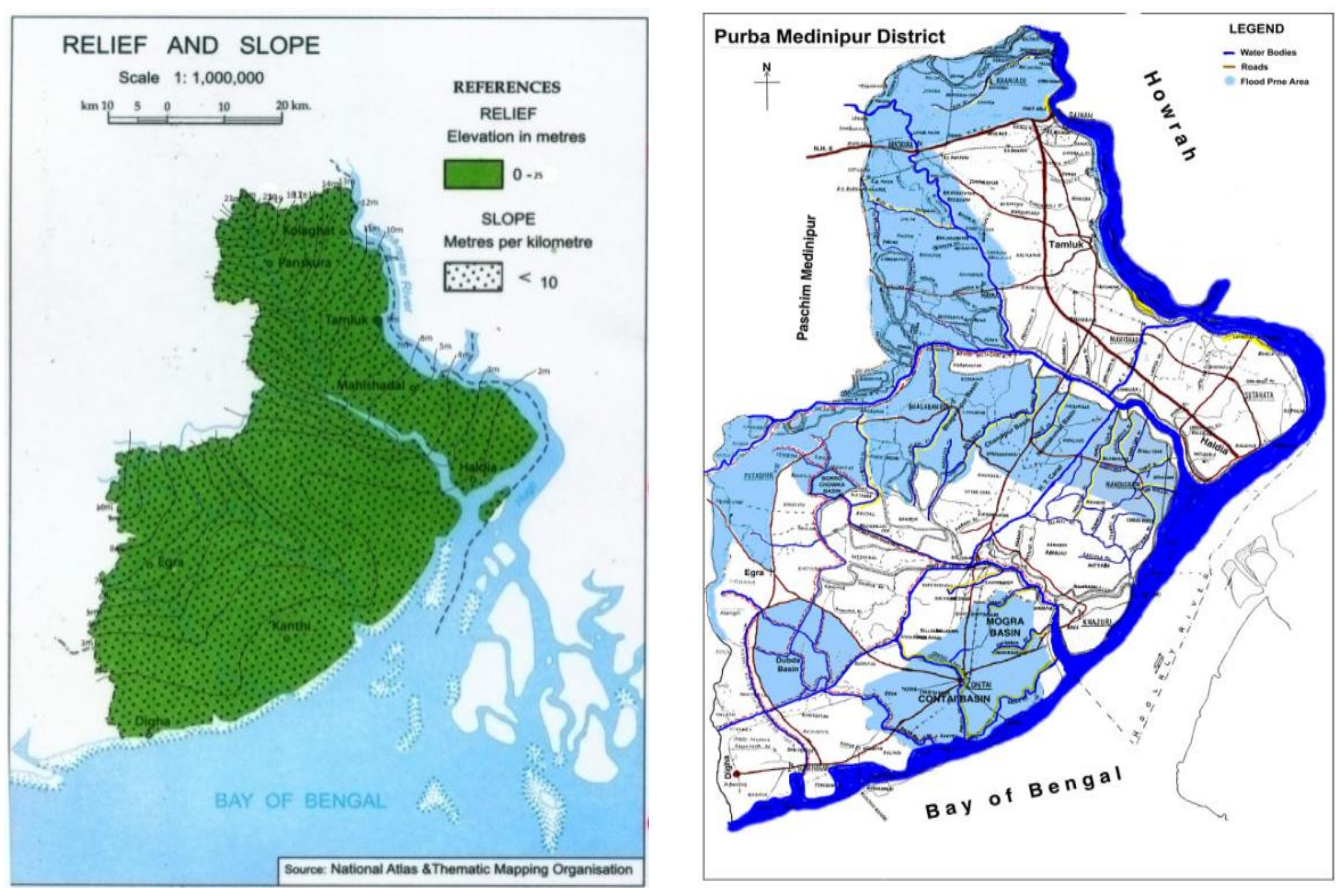

VIII. IMPACT OF SEASONAL AND COASTAL FLOODS IN STUDY AREA

Most part of the study area is frequently affected by some of the major geomorphic events among which coastal flood play the dominant role to change the land use pattern and agricultural practices. The major causative factors behind this geomorphic event are the nature of topography and relief of the study area. Apart from these, there are many more factors which are directly and indirectly involved to change the conventional agricultural practices. The following table represents the author's observation on the cause and impact of this geomorphic event on the study area and its surrounding coastal parts.

\begin{tabular}{|c|c|c|}
\hline $\begin{array}{l}\text { Geomorphic } \\
\text { approach }\end{array}$ & Factors \& Causes & Effect. \\
\hline Coastal Flood & $\begin{array}{l}\text { 1. Extensively low gradient coastal } \\
\text { plain topography. } \\
\text { 2. Relatively low lying flat surface } \\
\text { (elevation- } 1.7 \mathrm{~m} \text { to } 2.5 \mathrm{~m} \text { ). } \\
\text { 3. High frequency of drainage and } \\
\text { channel alignment } \\
\text { 4. Surface depressions. } \\
\text { 5. Large catchment area of river basin. } \\
\text { 6. The monsoon spillage. } \\
\text { 7. Heavy rainfall in the coastal } \\
\text { depression. }\end{array}$ & $\begin{array}{l}\text { 1. Change of Land use and } \\
\text { agricultural practice. } \\
\text { 2. Loss of standing crops. } \\
\text { 3. Crop damages. } \\
\text { 4. Damage of fish stocks and its } \\
\text { related resource. } \\
\text { 5. Damage of fish farm. } \\
\text { 6. Loss of aqua cultivation in coastal } \\
\text { zone. }\end{array}$ \\
\hline
\end{tabular}

The following table indicates the analysis of various geomorphic events from 1932 to 2012 in and around the study area. There we come to know the cause and effect of different geomorphic determinants and their longtime impact of those coastal area geomorphic events. The authors find the associated problems which are directly put a signature on the land use pattern and agricultural perspective. The coastal erosion is the main factors to change the amount of agricultural land. Later a flood map of the study area indicates the affected area and its intensity.

\begin{tabular}{|c|c|c|c|}
\hline Year & Effect \& cause & Effected area & Associated problem in agriculture \\
\hline \multirow{2}{*}{$\widetilde{\Xi}$} & $\begin{array}{c}\text { Cyclonic storm and } \\
\text { Tidal wave and cyclone, } \\
\text { Storm surge, Heavy Rainfall } \\
\text { Depression, Riverine flood. }\end{array}$ & $\begin{array}{c}\text { Digha shore line, } \\
\text { Digha estuary, } \\
\text { Kanthi Coastal zone, }\end{array}$ & $\begin{array}{c}\text { Damage of Crop, } \\
\text { Fishing pond, } \\
\text { Forest cover }\end{array}$ \\
\hline
\end{tabular}




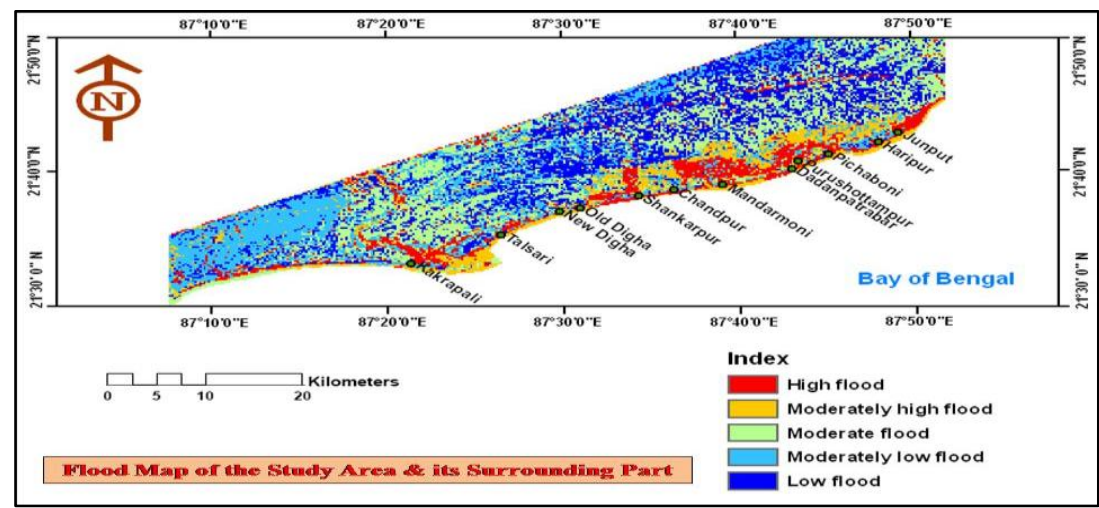

\begin{tabular}{|c|c|c|}
\hline $\begin{array}{c}\text { Geomorphic } \\
\text { approach }\end{array}$ & Factors \& Causes & Effect \\
\hline Shifting of sand dune & $\begin{array}{l}\text { 1. Beach Morphology. } \\
\text { 2. Coastal erosion. } \\
\text { 3. Textural composition of } \\
\text { beach and shore erosion. } \\
\text { 4. Wind velocity is increase at } \\
\text { the ground surface and } \\
\text { coastal part. } \\
\text { 5. Wind wave and Wind } \\
\text { stream. } \\
\text { 6. Sea wind and cyclonic } \\
\text { storm }\end{array}$ & $\begin{array}{l}\text { 1. Change of Coastal Morphology. } \\
\text { 2. Changing of coastal land forms } \\
\text { 3. Land use and agricultural } \\
\text { practice change. } \\
\text { 4. Damage of fish stocks and its } \\
\text { related resource. } \\
\text { 5. Damage of fish farm. } \\
\text { 6. Loss of aquaculture in coastal } \\
\text { zone. }\end{array}$ \\
\hline
\end{tabular}

The above table indicates the analysis of the geomorphic cause and impact of the shifting of sand dunes in and around the coastal area. There we also find an outcome of the cause and effect of different geomorphic determinants and their longtime impact of those coastal area geomorphic events especially shifting of sand dunes. The authors are in a position to highlight the impact on the agricultural activities and land use pattern, which are the resultant factors of the said geomorphic determinant.

The authors put some photographic scenario to prove the geomorphic events like soil loss, coastal erosion, shifting of sand dunes towards the agricultural lands, land reclamation, change of land use pattern, river bank erosion etc of the study area and its surrounding part.
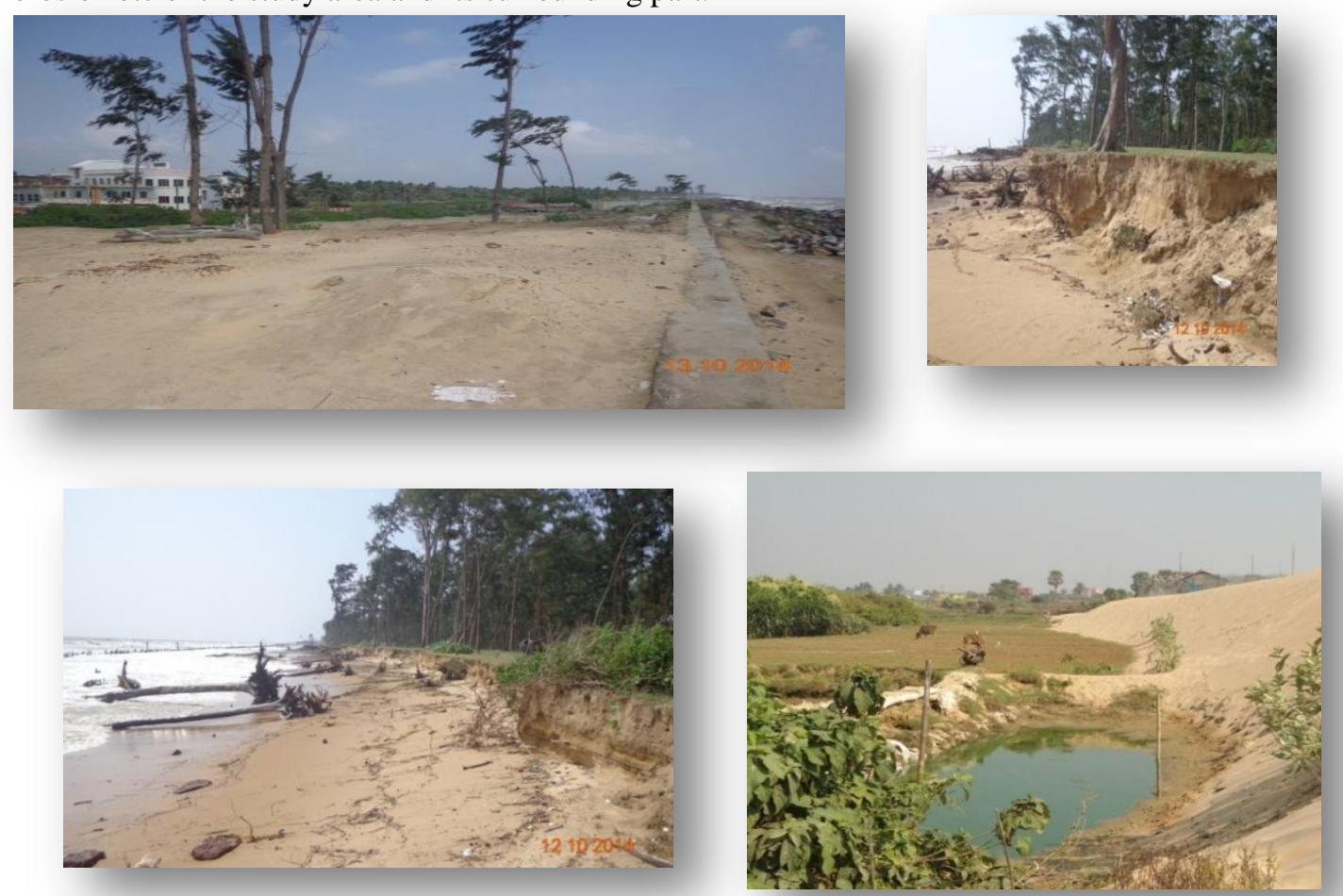

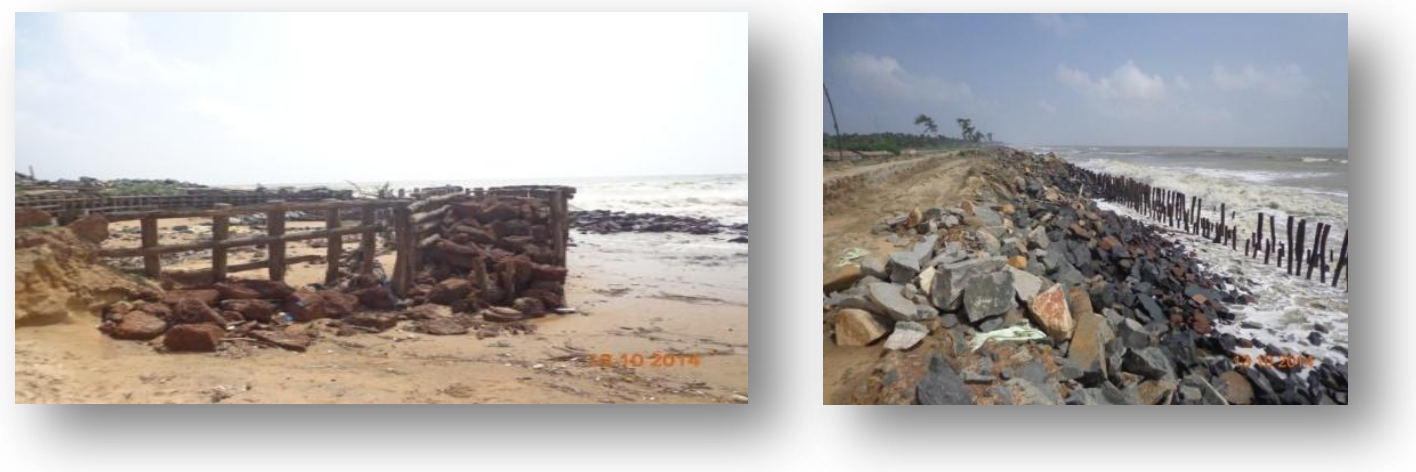

IX.

LAND USE AND AGRICULTURAL PRACTICE

Contai (Kanthi) coastal plain is high riche resource area of Purba Medinipur, W.B. Most of the geographic regions of this part are generally covered with agriculture related economic activities. Food crop, commercial crop, plantation crop, horticultural crop and water based aquaculture take place in this region. Because geographic terrain based coastal \& seasonal flood and coastal erosion are not favorable for food crop (rice) agriculture. So the habituated people rapidly change (dynamic change) their agricultural practices.

\begin{tabular}{|c|c|c|c|c|c|c|c|}
\hline \multicolumn{8}{|c|}{ CHANGING LAND USE PATTERN AND AGRICULTURAL PRACTICE } \\
\hline \multirow{2}{*}{\multicolumn{2}{|c|}{$\begin{array}{l}\text { Study \& Survey Area } \\
\text { (Ramnagar Block-I) }\end{array}$}} & \multicolumn{3}{|c|}{$\begin{array}{l}\text { Previous Land Use and Agricultural } \\
\text { practice engage person in \% (before } \\
\text { 2000) }\end{array}$} & \multicolumn{3}{|c|}{$\begin{array}{l}\text { Present Land Use and } \\
\text { Agricultural practice engage } \\
\text { person in \% (2012-2013) }\end{array}$} \\
\hline & & Agriculture & Fishing & Other & Agriculture & Fishing & Other \\
\hline \multirow{3}{*}{$\begin{array}{c}\text { Talgachari-II } \\
\text { Gram Panchayat }\end{array}$} & Dolbolda Village & 71 & 3 & 26 & 50 & 10 & 40 \\
\hline & Lachimpur Village & 68 & 12 & 20 & 56 & 31 & 13 \\
\hline & Jamra Village & 65 & 7 & 37 & 51 & 21 & 28 \\
\hline \multirow{3}{*}{$\begin{array}{c}\text { Alankerpur } \\
\text { Gram Panchayat }\end{array}$} & Somaibosan & 72 & 9 & 19 & 61 & 13 & 24 \\
\hline & Gangadharpur & 61 & 6 & 23 & 55 & 17 & 28 \\
\hline & Jogaibosan & 75 & 7 & 18 & 60 & 23 & 17 \\
\hline
\end{tabular}

Source: Field Investigation and Socio-Economic Survey \& Compiled by the Authors

\section{CONCLUSION \& RECOMMENDATION}

The Contai (Kanthi) coastal plain is a very high rich resource region mainly agricultural crop grown throughout the year. So Socio economic conditions of the coastal people depend on agricultural practice and products. However, their economic status is well and good. But, during the recent time, change of soil fertility, mainly low level fertility, salt water invasion ,shifting of dunes, shifting of shore line, Channel bank erosion and also coastal erosion are the most effective and deterministic morphological activities to change the existing land use pattern and change of agricultural practice. About $75 \mathrm{sq} \mathrm{km}$ area of the coastal tract under goes to changing of agricultural practice. So it is the right time to think a valuable plan of the protection of agricultural land and a proper management way for the agricultural practice to keep sustainable development of the local habitant of these coastal belts of West Bengal. Because, the poor people highly depends on their land, soil, agriculture and agricultural practices even in this progressive time. To protect the agrarian economy the strategic plan and programmes should be adopted by the Government immediately because -

$\checkmark$ Agriculture is the primary economic activity for growth and development of economic status.

$\checkmark \quad$ The agriculture is mostly dominated agro-based economy in the past and present scenario.

$\checkmark$ Agriculture still holds the key of economic life in most of the developing nation, state, District and Block and also other small geographical sector/region.

$\checkmark$ According to HDI report: - Global labour force is directly engaged in agriculture activities (1970-85\%, $1990-76 \%, 1998-49 \%, 2012-54 \%$.

$\checkmark$ Agricultural lands are occupied for urbanization and land transformation due to urban growth.

$\checkmark$ Existing agriculture lands are determined by some geomorphic attribute, these are terrain, ruggedness of relief, slope, erosion, hydrological quality and paedological setup quality.

$\checkmark$ Land productivity and agricultural prospect determines some geomorphic interaction between geomorphology and geo environment.

$\checkmark$ These are very essential for the planning and development of the Agriculture and Agro based urban environment location. 


\section{POLICY OF FUTURE PLANNING OF THE STUDY AREA}

Some initiatives can be taken for the growth and development of the agrarian activities and economy to cope up with the future demands. To maintain the agricultural system and their practices the following strategy may be recommended for the future planning.

> Global Environmental Monitoring System (GEMS) applicable on regional sector.

$>$ Sustainable agricultural development.

$>$ Expansion of urban areas should not be encouraged at fertile agricultural land.

$>$ Development of rural infrastructure for land-suitable crop cultivation.

$>$ Development of agro-irrigation system for Agricultural exploration.

$>$ Soil and land conservation strategies

$>$ No investment on less fertile land for agriculture.

$>$ Scientific system and techniques use for agriculture and crop pattern development.

$>$ Good well communication on national and international agro based research Center.

$>$ To needs agro-urban prospect report analysis, interpretation and development of information technology use and interaction on local, regional, block level, state level, national and also international field.

\section{REFERENCES}

[1] Ahamad, E. (1972). Coastal Geomorphology of India Orient Longman Ltd. New Delhi. 222p.

[2] Chakraborti, A. (1965). Geomorphology and Beach sedimentation around Digha, W.B., India. Unpublished Ph.D. Thesis. IIT. Kharagpur. 550. CHA/G. Ph.D. 341

[3] Chatterjee, P.K. (1972).Beach erosion in the area around Digha, Midnapur disctict, W.B. and its influence on ground water characteristics. Proc. Geom. Geohyd. Geotech, Lower Ganga Basin. IIT. Kharagpur. Pp.B 19-24.

[4] Paul, Ashis kr. (1988). Morphoecological dynamics of the Coastal tract of West Bengal. Ph.D. Thesis in Geography. Univ. of Calcutta. 218p.

[5] Paul, Ashis Kr. (1996). Identification of coastal hazards in West Bengal and part of Orissa. India Journal of Geomorphology. Vo. 1. No. 1. New Delhi, Academic and law serials. pp. 1-27.

[6] Paual, Ashis Kr. (2002). Coastal Geomorphology And Environment acb publication Kolkata p. 757.

[7] Pethic, J. (1984).An Introduction to coastal geomorphology. Arnold-Heinemann. London p.260.

[8] Pethic, J. (1992). Natural change. In. Coastal zone planning and management. Thomas Telford, Londan. pp. 243-280.

[9] Ray, T. K. and Baksi, S.K. (1978) Coastal sanddunes of Fraserganj island. West Sundarban. W.B. India Jour. Eerth Sciences. Vol.5 no.1, Kolkata. pp. 121-123.

[10] Sen Sarma, S.B. (1990). Stability of East Coast of India, An overview. Marine News Letter. pp. 4-8.

[11] Umitsu, M (1997). Landforms and Floods in the Ganga Delta and Coastal Lowland of Bangladesh. M arine Geodesy. No. 20. pp. 77-87.

[12] Yadav, J.S.P. Bondopadhyay, A.K. and Bondopadhyay, B.K. (1983). Extreme of costal saline soils of India, Jour. Ind. Soc. Coastal Agri, Research, vol. 1.pp. 1-6. 